\title{
NPR1 and Redox Rhythm: Connections, between Circadian Clock and Plant Immunity
}

\author{
Jingjing Zhang 1,2, Ziyu Ren ${ }^{1,2}$, Yuqing Zhou ${ }^{1,2}$, Zheng Ma 1,2,3, Yanqin Ma 1,2,3, Dairu Hou 1,2, \\ Ziqin $X u^{1,2,3}$ and Xuan Huang 1,2,3,* \\ 1 Provincial Key Laboratory of Biotechnology of Shaanxi, Xi'an 710069, China; \\ twinklezhang@stumail.nwu.edu.cn (J.Z.); reneeziyu@stumail.nwu.edu.cn (Z.R.); \\ desertree0302@163.com (Y.Z.); 0mazheng0@stumail.nwu.edu.cn (Z.M.); \\ mayanqin@stumail.nwu.edu.cn (Y.M.); dairuhou@stumail.nwu.edu.cn (D.H.); ziqinxu@nwu.edu.cn (Z.X.) \\ 2 College of Life Sciences, Northwest University, Xi'an 710069, China \\ 3 Key Laboratory of Resource Biology and Biotechnology in Western China, Ministry of Education, \\ Xi'an 710069, China \\ * Correspondence: xuanhuang@nwu.edu.cn; Tel.: +86-29-8830-2411; Fax: +86-29-8830-3572
}

Received: 29 January 2019; Accepted: 6 March 2019; Published: 10 March 2019

\begin{abstract}
The circadian clock in plants synchronizes biological processes that display cyclic 24-h oscillation based on metabolic and physiological reactions. This clock is a precise timekeeping system, that helps anticipate diurnal changes; e.g., expression levels of clock-related genes move in synchrony with changes in pathogen infection and help prepare appropriate defense responses in advance. Salicylic acid (SA) is a plant hormone and immune signal involved in systemic acquired resistance (SAR)-mediated defense responses. SA signaling induces cellular redox changes, and degradation and rhythmic nuclear translocation of the non-expresser of $P R$ genes 1 (NPR1) protein. Recent studies demonstrate the ability of the circadian clock to predict various potential attackers, and of redox signaling to determine appropriate defense against pathogen infection. Interaction of the circadian clock with redox rhythm promotes the balance between immunity and growth. We review here a variety of recent evidence for the intricate relationship between circadian clock and plant immune response, with a focus on the roles of redox rhythm and NPR1 in the circadian clock and plant immunity.
\end{abstract}

Keywords: plant immunity; circadian clock; SA-signaling network; NPR1; redox rhythm; $\mathrm{NADH} /$ nicotinamide adenine dinucleotide phosphate (NADPH); reactive oxygen species (ROS)

\section{Introduction}

Most eukaryotic and some prokaryotic organisms have some type of circadian clock that functions as an internal timing mechanism for the control of various normal physiological reactions under light/dark cycle, such as metabolism, hormone levels, body temperature, permitting vision, and brain activities processes [1-5]. The circadian clock is a rather robust system, especially in detecting the precise time of day processes in many metabolic and physiological reactions to help plants make the right reaction at the right time. Furthermore, it drives an endogenous oscillating rhythm strictly observe a period of approximately $24 \mathrm{~h}$ even if it is under continuous light or dark [6-9]. Diverse physiological pathways are connected with the circadian clock, including ion homeostasis, hormone signaling, sugar sensing, photoperiodic flowering and stress signaling. Increasing evidence has proved that plant immune response are also connected with the circadian clock [10-12]. Preserving circadian clock regulation during the day increases carbon dioxide fixation, growth, and fitness $[13,14]$. In addition, at least $30 \%$ of genes expression with robust oscillations in Arabidopsis are associated with physiological rhythms driven by the circadian clock [15]. 
Plants have evolved highly efficient defense mechanisms against a variety of major pathogens (e.g., Pseudomonas syringae, Golovinomyces cichoracearum, Botrytis cinerea, Alternaria brassicicola) [16-18]. There are two "branches" of triggered immunity in plants. (i) PAMP/MAMP-triggered immunity (PTI/MTI) is triggered by conserved pathogen or microbe-associated molecular patterns (PAMPs, MAMPs) [19]. Specific pattern recognition receptors (PRRs), such as EF-Tu receptor (EFR) and FLAGELLIN-SENSING 2 (FLS2) [20], recognize PAMPs or MAMPs and trigger PTI/MTI for resistance to biotrophic cellular pathogens, viruses, and insects [21]. (ii) Effector-triggered immunity (ETI), which is triggered by specific recognition between pathogen effectors and immune receptors in a host cell, generally encompasses a programmed cell death at the site of pathogen recognition known as the hypersensitive response (HR), and the receptors encoded by resistance genes ( $R$ genes) [22-24]. Subsequently (hours or days later), systemic acquired resistance (SAR) occurred following HR, which evidently result from cooperative activation of numerous genes termed pathogenesis-related $(P R)$ genes [25-28]. Salicylic acid (SA), a plant hormone involved in development and basal resistance against multiple pathogens, is a key regulator of pathogen-induced SAR [29-34].

Numerous studies indicate a relationship among circadian clock, plant immunity, and reductionoxidation (redox) rhythm [35-37]. Accumulation of reactive oxygen species (ROS) induced by PTI may prevent pathogen invasion [38]. ETI induces programmed cell death associated with changes in nicotinamide adenine dinucleotide phosphate (NADPH) oxidase activity that has been evidenced as the source of ROS [39]. Non-expresser of PR genes 1 (NPR1, also known as NIM1 and SAI1) [40] regulates expression of clock genes and is also involved in plant defense response through its role in SA signaling [41,42]. In coordination with circadian clock changes, SA regulates expression of downstream defense genes in response to pathogen behavior [43]. In this article, we review interactions between circadian clock and plant immune system, we focus on recent advances in rhythmic oscillation of both redox and clock, and on metabolic and physiological reactions that promote balance of plant immunity and growth.

\section{Relationship between Circadian Clock and Immune Responses}

The core element of the circadian systems is an oscillator based on a transcription-translation negative feedback loop [44,45]. The circadian clock regulates plant innate immunity to invasion by exogenous pathogens. The coordination between biotrophic pathogens and host provides a daily schedule for plants to defend against exogenous pathogens, that plant defense may related to circadian clock. $[6,8,46]$. However, the link between them has never been firmly established.

\subsection{The Core Loop of Circadian Clock}

A. thaliana has a core loop structure of interrelated morning and evening loops which encodes molecular components of the circadian oscillator. Two partially redundant morning-phased genes, CCA1 (CIRCADIAN CLOCK ASSOCIATED 1) [47] and LHY (LATE ELONGATED HYPOCOTYL) [48] have transcript and protein levels that peak in the morning and activate expression of $P R R$ family genes (PRR5, PRR7, and PRR9/NI; PSEUDO-RESPONSE REGULATORs 5, 7, 9/night inhibitor) through direct association with their promoters [49,50]. PRR family genes also suppress CCA1 and LHY expression by binding to their promoters. PRR1, the eponymous member of the PRR family, is also referred to as evening-phased TOC1 (TIMING OF CAB 1) [51,52]. In antiphase to TOC1 peak in early evening, $\sim 40 \%$ of TOC1 target genes have an early morning phase regulated by circadian clock [53].

Loss of core loop elemental genes notably speeds up the clock [54]. Feedback loops have been shown to form the circadian clock and to regulate rhythms of output genes whose expression is reflected in behavioral and physiological rhythms in response to environmental changes throughout the day $[55,56]$. LHY and CCA1 have both been shown to regulate TOC1, LHY, and CCA1 gene expression negatively (Figure 1) $[47,56,57]$. TOC1 acts as a repressor that directly binds to CCA1 and LHY promoters in early evening [58,59]. Mutations of CCA1 (cca1-1), LHY (lhy-20) and TOC1 (toc1-2) did not completely disrupt clock rhythm. Loss-of-function Arabidopsis mutants, in comparison with 
wild-type, showed shorter appropriate duration of circadian rhythms and reduced fitness [13,52,60-62]. Semi-dominant toc1-1 mutant revealed the strong effect of TOC1 on clock-controlled output processes (Table 1) [63]. CCA1 and LHY proteins evidently have analogous functions and, even if one of them is absent, the other is able to maintain circadian rhythm.

Table 1. Core loop genes are direct regulators of plant defense.

\begin{tabular}{|c|c|c|c|c|c|}
\hline Gene Name & \multicolumn{2}{|c|}{ CCA1 } & \multicolumn{2}{|c|}{$L H Y$} & TOC1 \\
\hline $\begin{array}{l}\text { Expression } \\
\text { phase }\end{array}$ & \multicolumn{2}{|c|}{ Morning } & \multicolumn{2}{|c|}{ Morning } & Evening \\
\hline $\begin{array}{c}\text { Clock } \\
\text { phenotypes }\end{array}$ & \multicolumn{2}{|c|}{ Shorter periods } & \multicolumn{2}{|c|}{ Shorter periods } & Shorter periods \\
\hline $\begin{array}{l}\text { Relationship } \\
\text { to core loop }\end{array}$ & \multicolumn{2}{|c|}{$\begin{array}{c}\text { Negatively regulates } T O C 1, L H Y \text { and } \\
\text { CCA1 gene expression }\end{array}$} & \multicolumn{2}{|c|}{$\begin{array}{l}\text { Negatively regulates TOC1, } L H Y \text { and } \\
\text { CCA1 gene expression }\end{array}$} & $\begin{array}{l}\text { Repressor directly } \\
\text { binding to CCA1 and } \\
\text { LHY promoters in } \\
\text { early night }\end{array}$ \\
\hline $\begin{array}{l}\text { Expression } \\
\text { influencing } \\
\text { factors }\end{array}$ & \multicolumn{2}{|c|}{$\begin{array}{c}\text { Affected by flg22, RPP4, and infection } \\
\text { by } P \text {. syringae, } H \text {. arabidopsidis, } \\
\text { and B. cinerea }\end{array}$} & \multicolumn{2}{|c|}{ Increased by SA } & $\begin{array}{l}\text { Increased by SA and } \\
\text { suppressed by } \\
\text { mutations disrupting } \\
\text { ICS1, NPR1, or ROS }\end{array}$ \\
\hline Types & Mutants & Overexpression & Mutants & Overexpression & $\begin{array}{l}\text { Signaing } \\
\text { Mutants }\end{array}$ \\
\hline Susceptibility & $\begin{array}{l}\text { More susceptible } \\
\text { to } P \text {. syringae, } H \text {. } \\
\text { arabidopsidis, and } \\
\text { B. cinerea }\end{array}$ & $\begin{array}{l}\text { More susceptible } \\
\text { to } P \text {. syringae, } T \text {. } \\
\text { ni More resistant } \\
\text { to } H \text {. arabidopsidis }\end{array}$ & $\begin{array}{l}\text { More susceptible } \\
\text { to } P \text {. syringae, } H \text {. } \\
\text { arabidopsidis, } \\
\text { and B. cinerea }\end{array}$ & $\begin{array}{l}\text { More susceptible } \\
\text { to } P \text {. syringae }\end{array}$ & $\begin{array}{l}\text { Higher SA-induced } \\
\text { resistance to P. syringae }\end{array}$ \\
\hline References & \multicolumn{2}{|c|}{$[35,47,51,57,61,62,64-68]$} & \multicolumn{2}{|c|}{$[35,47,51,57,61,62,65,68]$} & $\begin{array}{c}{[13,35,42,45,52,58,59} \\
65,69-72]\end{array}$ \\
\hline
\end{tabular}

\subsection{Regulation of Plant Immunity by Circadian Clock/Rhythm}

Numerous studies have demonstrated direct regulation of plant immunity by circadian clock. PTI and ETI will be triggered through regulating evening-phased elements in plants involved in the circadian clock.

\subsubsection{CCA1 Reduces Plant Susceptibility to Pathogens}

Clock gene CCA1 suppresses plant susceptibility to pathogens. It enhances pathogen resistance at dawn, as evidenced by changes in loss-of-function mutants of susceptibility to Hyaloperonospora arabidopsidis (Hpa) Emwa1, the cause of downy mildew disease in Arabidopsis leaves (Figure 1) [73,74]. CCA1 encodes the transcription factor that contain a single MYB domain. Resistance to downy mildew was enhanced in a CCA1 overexpression mutant (CCA1-ox) (Table 1) [47]. Resistance to pathogens at dusk is reduced in CCA1 deletion mutants (Table 1) [75]; these plants show greater resistance in the morning and greater susceptibility in the evening. Rhythmic susceptibility changes throughout the day in Arabidopsis interaction with virulent biotrophic pathogen P. syringae pv. tomato DC3000 (DC3000), which triggers PTI, were not observed in CCA1-ox and EARLY FLOWERING 3-1 mutants (elf3-1), indicating the ability of circadian clock to regulate the host immune response [76]. Defense response of ETI is more intense than that of PTI. Some plants recognize effector molecules secreted by pathogens through $R$ genes, and then activate ETI to strengthen the defense response [30].

(1) CCA1, LHY, and TOC1 form the core loop of transcription-translation feedback loops that regulate daily timekeeping. CCA1 and $L H Y$ have transcript and protein levels that peak in the morning, TOC1 peaks in early evening and acts as a repressor that directly binds to CCA1 and $L H Y$ promoters. $\sim 40 \%$ of TOC1 target genes have an early morning phase regulated by the circadian clock. LHY and CCA1 have both been shown to regulate TOC1 negatively. (2) CCA1 and LHY activate expression of $P R R$ family genes through direct association with their promoters. $P R R$ family genes also suppress CCA1 and $L H Y$ expression by binding to their promoters. (3) CCA1 and $L H Y$ regulate $G R P 7$, a key constituent of a slave oscillator that modulates stomatal activity related to plant immune response, is involved in regulation of plant immunity. Stomatal opening at dawn and 
closure at noon. (4) Morning-phased $L H Y$ and CCA1 positively regulate resistance against oomycete pathogen $\mathrm{Hpa}$ and bacterial pathogen $P$. syringae, whereas evening-phased TOC1 negatively regulates resistance against bacteria. Spore formation of oomycete pathogen occurs mainly at night, and spores, therefore, germinate at dawn. (5) Maximal JA accumulation occurs around midday, whereas SA peaks around midnight, cytosolic NPR1 suppressed JA signaling. (6) NPR1 plays essential roles in binding of SA. NPR1 oligomers become monomers under pathogen infection, and this process triggers SA accumulation. In the absence of SA or pathogen challenge, NPR1 is degraded by the proteasome and its inhibitory effect on effector-triggered cell death and anti-pathogen defense is eliminated. (7) Under anti-pathogen defense response or SA induction, NPR1 is converted into monomers, which can be combined with TGA2 transcription factor to promote $P R$ gene expression, and are released (transferred) from cytoplasmic sites to the nucleus. GSNO facilitates Cys156 disulfide bonding and promotes NPR1 oligomer formation. Both TRX-3h and TRX-5h catalyze monomerization of NPR1 and prevent its repolymerization.

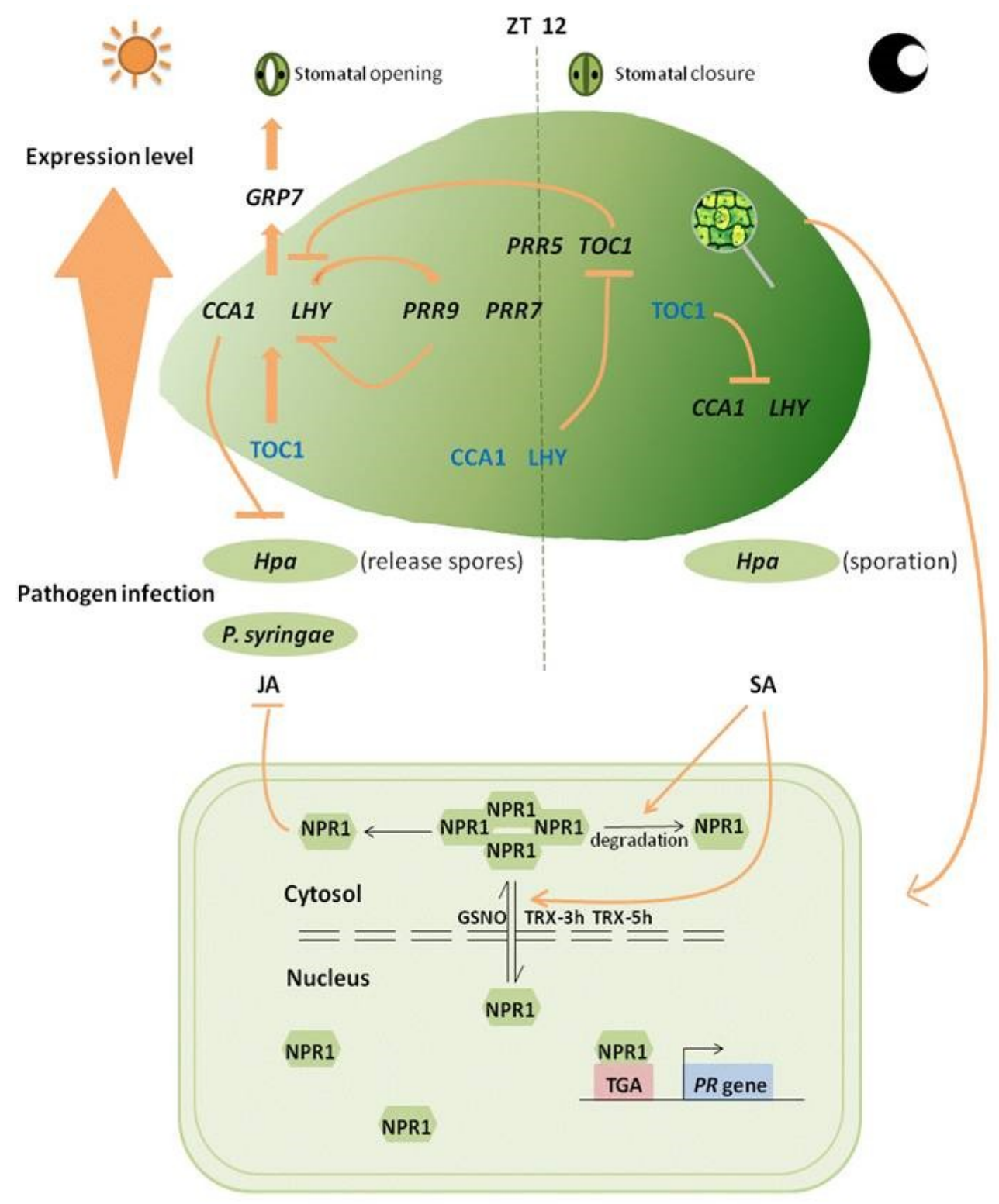

Figure 1. Circadian clock genes changes affect plant defense. 
Even in the absence of pathogen invasion, plants are programmed to deal with pathogen infection on the basis of a circadian clock schedule. Appropriate clock function plays a key role in defense responses. Spore formation of oomycete pathogen occurs mainly at night, and spores therefore germinate at dawn [77]. Defense response-related genes have adapted to such timing by peaking around midnight and dawn (Figure 1); an example is CCA1, overexpression of which enhances resistance in Arabidopsis defense response [47]. Hpa EmwaI defense in Arabidopsis stimulated not only programmed cell death but also basal resistance through RECOGNITION OF PERONOSPORA PARASITICA 4 (RPP4), whose promoters show close association with the circadian clock. Expression of $R P P 4$ and its target genes shows broad overlap with CCA1 rhythm, CCA1 can promote the expression of the target defense genes related to programmed cell death (PCD) by activating RPP4 directly [64]. Certain other RPP4-target defense genes independent of RPP4 can also be activated by regular changing CCA1 level for basal defense. The dual activation mode is resulting in a more powerful and efficient defense response [12].

\subsubsection{Does CCA1 Regulate Non-Clock-Related Activities?}

Does CCA1 plays a role in regulation of non-clock-related activities for enhancement of anti-pathogen defense responses? As an output of the circadian clock, plant immune response is regulated by the clock under both constant light and circular lighting (12 hr light/12 hr dark). Under both these light conditions, susceptibility to avirulent $P$. syringae strain was greater for CCA1-ox plants than for wild-type, the opposite of this, CCA1-ox plants showed an enhanced resistance to Hpa [46,62]. Both cca1-1/lhy-20 double mutant and LHY-ox plants showed enhanced susceptibility to avirulent $P$. syringae, and cca1-1/hy-20 double mutant also showed enhanced susceptibility to oomycete pathogen Hpa strains under circular lighting. Although CCA1 and LHY mutants showed similarly shortened circadian period, CCA1-ox plants show enhanced immune response to Hpa, but LHY does not show a defense response against $\mathrm{Hpa}$ [64]. These findings suggest that the circadian clock regulates plant innate immunity as an output under both light conditions, however, whether the enhanced resistance to Hpa in CCA1-ox plants is caused by non-clock function resulting from CCA1 overexpression is still unclear.

\subsubsection{Interactions between Plant Immunity and Circadian Clock/Rhythm}

Mutual regulation between the circadian clock and plant immune response was observed in the clock-related gene mutants mentioned above, and further investigation showed that defense response was under the control of the circadian clock. When circadian clock rhythm resulting from CCA1 or $L H Y$ overexpression was disrupted, susceptibility to $P$. syringae strain was greatly enhanced. CCA1 and LHY regulate their downstream target gene GLYCINE-RICH RNA-BINDING PROTEIN 7 (GRP7), which is involved in regulation of plant immunity and is a key constituent of a slave oscillator [78-80] that modulates stomatal activity related to plant immune response [81]. Interestingly, the circadian clock regulates plant defense response, and defense response in turn regulates the circadian clock. For example, treatment of avirulent $P$. syringae strain infection or of flg22 (a resulting flagellin protein) is associated with modulation of clock activity [62].

SA can be transiently produced upon infection [82]. A previous finding has shown that the amplitude of clock rhythms will increase under SA treatment [42]. In contrast to this, a lately study observed both SA treatment and Pst DC3000 infection decrease the amplitude of clock rhythms [83]. The sharp different result may caused by different SA concentrations or plants age [84,85]. Notably, SA treatment leads to a negative phase shift, which instead a slight phase advance in Pst DC3000 infection plants, only Pst DC3000 infection plants lengthened the clock period, which has no evident change under SA treatment [83]. Altogether, these data suggests that the ultimate clock phenotypes show in infection plants is due to SA-dependent and -independent pathways integration.

The stress- and defense-related hormone JA undergoes a rhythm oscillator as well. The clock regulates JA levels with a peak in the midday [69]. In Arabidopsis, the clock protein CCA1 are able to 
bind to the JA biosynthetic gene promoter LIPOXYGENASE2 [86]. The circadian clock can regulate the expression of the JA receptor CORONATINE INSENSITIVE1, as well as the expression of MYC2, a positive transcription factor of JA signaling. TIME FOR COFFEE (TIC) acts as a key determinant in circadian clock, also acts as a negative transcription factor in JA-mediated defense responses. It was found to inhibit the transcription of CORONATINE INSENSITIVE1 to repress MYC2 protein accumulation [87].

\section{Plant Immune Responses Involving Salicylic Acid (SA) and Jasmonic Acid (JA)}

The plant hormone SA is produced in response to biotrophic pathogens invasion and induces SAR and JA is essential for the defense against necrotrophic pathogens and herbivorous insects [31]. Oscillation of hormones level plays a key role in proper coordination of immune response and plant development. The SA-signaling network involves transcription co-activators NPR1, NPR3, and NPR4. Whether NPR1 is a receptor of SA remains unclear [88,89].

\subsection{Role of SA and JA in Coordinating Plant Immune Response and Growth}

Recent chromatin immunoprecipitation studies indicate that morning-phased CCA1, eveningphased TOC1, and PPR family genes can combine with hundreds of gene promoters [59,86,90-92]. Circadian clock-related elements are regulated directly by plant hormones such as SA and jasmonic acid (JA), not by chance [93]. Maximal JA accumulation occurs around midday, whereas SA peaks around midnight [69]. ISOCHORISMATE SYNTHASE 1 (ICS1) is a direct clock target gene that encodes a key enzyme involved in SA biosynthesis. ICS1 expression is controlled by CCA1 HIKING EXPEDITION (CHE), a transcription factor of evening-phased elements [65]. ICS1 gene expression, like SA accumulation, peaks at midnight and is involved in pathogen infection in the morning.

Morning-phased $L H Y$ and $C C A 1$ positively regulate resistance against oomycete pathogen $H p a$ and bacterial pathogen P. syringae [62,87], whereas evening-phased TOC1 negatively regulates resistance against bacteria. With SA treatment in the subjective morning or evening under $3 \mathrm{~h}$ constant light, defense-related genes showed increased expression mainly $3 \mathrm{~h}$ after morning SA application [42], whereas genes related to growth and development showed increased expression mainly after evening SA application. SA treatment has a consistent effect on redox rhythm, and morning application has a positive effect on plant defense $[87,94]$, whereas evening application has a negative effect. Such a shift of plant defense during the course of a day may reflect adaptation to changing diurnal physical conditions; temperature and humidity in the morning are typically more conducive to pathogen challenge [64]. The clock system also regulates plant defenses via other clock-related genes such as phosphate transporter gene PHOSPHATE TRANSPORTER 4;1 (PHT4;1), which is regulated by CCA1, a negative regulator of SA signaling [95]. SA functions in both local defense against biotrophs and as an essential signal in distal organization for broad-spectrum SAR [33].

A functional JA signaling pathway is required for oscillation in susceptibility to the fungus Botrytis cinerea [68]. In Arabidopsis, SA produced during pathogen infection strongly antagonizes both JA biosynthesis and JA-responsive gene expression, resulting in a large set of JA-responsive genes, including LIPOXYGENASE2 (LOX2), VEGETATIVE STORAGE PROTEIN (VSP), and PLANT DEFENSIN 1.2 (PDF1.2) down regulated [93]. Plants may show negative responses to inappropriate stimuli; e.g., inappropriate induction of immunity at night may inhibit plant growth. Experimental SA treatment of plants under constant dark conditions helped maintain stronger circadian rhythm, but caused a major reduction of fresh weight. SA treatment also had an inhibitory effect on the expression of various defense-related aquaporin genes. An aqueous environment is generally essential for pathogen virulence. Thus, timing of SA-mediated immune responses in the morning helps avoid conflict between SA immune response and growth-related activities that require water transport at night [96]. 


\subsection{Is NPR1 an SA Receptor?}

Recently, some data clearly pointed out that NPR1 has high-affinity to bind with SA [97]. Increasing evidence strongly supports the idea that NPR1 plays a key role in SA signaling and as an SA receptor.

\subsubsection{Molecular Structure of NPR1}

The NPR1 gene was first discovered through genetic screening of Arabidopsis mutants showing defects of SA-mediated pathogen resistance $[24,25,91,98,99]$. NPR1 was cloned as a novel protein containing a bipartite nuclear localization signal, two protein-protein interaction domains, $\mathrm{N}$-terminal bric-a-brac, tramtrack, and BTB/POZ (broad-complex, tramtrack, and bric-à-brac/poxvirus, zinc finger) domains, and an ankyrin-repeat domain with diverse functions [100-102]. The BTB/POZ domain is found in proteins that function as substrate adapters of CUL3-based ubiquitin ligases for the degradation of specific substrates [103].

\subsubsection{NPR1 Signal Transduction Pathway}

Both increase of endogenous SA levels and exogenous SA application lead to gene transcription that is greatly altered under pathogen induction [104]. NPR1, a transcription co-activator known as a "master" regulator of plant immunity, triggers change of SA level. NPR1 function requires direct combination of the transition metal copper with SA, similar to the requirement of phytohormone ethylene for copper [105]. The SA/NPR1 complex is sensitive to chelation by Ethylene Diamine Tetraacetic Acid (EDTA), and the combination between SA and NPR1 could not be detected until testing of equilibrium dissociation constant $(\mathrm{Kd})$ for incubation of SA with NPR1, coupled to the solid phase. The C-terminus of NPR1 contains two Cys residues (Cys521, Cys529) that play essential roles in binding SA to NPR1 [88].

The above findings clearly indicate that NPR1 is the SA receptor, and that they bind directly to each other. Partially reduced NPR1 oligomers become monomers under pathogen infection, and this process triggers SA accumulation (Figure 1) [33]. In the absence of SA or pathogen challenge, NPR1 is degraded by the proteasome and its inhibitory effect on effector-triggered cell death and anti-pathogen defense is eliminated [84]. For this, NPR1 requires Cullin-3 (CUL3)-based E3 ubiquitin ligase, a ligand with significant binding activity that can combine BTB domain-containing proteins [100,106-108]. NPR1 does not interact directly with CUL3, and it has, therefore, been proposed that association of CUL3 with NPR1 may be mediated by other adaptors that have the same domain as NPR1 [109]. NPR3 and NPR4, homologues of NPR1 that contain BTB domains, are good candidate adaptors [84,110]. npr3-1/npr4-3 double mutant showed enhanced level of $P R$ gene expression regardless of pathogen induction, and reduced susceptibility to both P. syringae pv. maculicola (P.s.m.) ES4326 and Hyaloperonospora parasitica Noco2. NPR1 protein stability thus makes the npr3-1/npr4-3 double mutant insensitive to SAR induction. Binding affinity to SA is higher for NPR4 $\left(K_{d}=\right.$ $23.54 \pm 2.742 \mathrm{nM})$ than for NPR3 $\left(K_{\mathrm{d}}=176.7 \pm 28.31 \mathrm{nM}\right)[84,88,111]$. Pathogen induction results in generation of an SA gradient whereby NPR1 accumulates in adjacent cells and promotes cell survival and SA-mediated resistance [112]. NPR1 may be degraded by NPR3 or NPR4 under stress, with suppression of programmed cell death during ETI at an infection site [23,89]. Surprisingly, the latest study shows that NPR1 functions separately with NPR3/NPR4. NPR3/NPR4 and may bind to SA at low levels to repress defense gene expression, the transcription co-activator NPR1 will promote defense gene expression on the accumulation of SA. Although both NPR1 and NPR3/4 are SA receptors, they function differently in transcriptional regulation of SA-induced defense gene expression, a NPR1 mutant loss the function in binding SA, it promotes SA-induced defense gene expression, whereas a NPR4 mutant represses SA-induced immune responses [97].

These findings, taken together, demonstrate the essential role of NPR1 as a receptor of SA, and also negative NPR3 and NPR4 controlling protein levels of NPR1 in plant immunity [84]. 


\subsection{Plant Defense Network Is Controlled by Cytosolic NPR1}

NPR1 as a key regulatory factor in the cross-talk between SA and JA signaling. Interaction between NPR1 and transcription factor TGA1 roles in the SA signaling, nuclear localization of NPR1 is not required for a plant defense network between SA and JA signaling, and therefore, the network is modulated by the NPR1 stays in cytosol [113]. Once the necrotrophic pathogens Alternaria solani and Botrytis cinerea are infected, the SA pathway will be manipulated through NPR1 and two JA-dependent defense genes expression including PROTEINASE INHIBITORS I and II will be suppressed for disease symptom development [68].

In brief, both JA and SA are of vital importance in plant immunity and thus coordinates the plant defense as well as growth regulation through various mechanisms.

\section{Central Role of NPR1 in SA-Mediated Plant Defense Response}

NPR1 is a key regulator of the SA-signaling network. SA induces degradation of NPR1, and NPR1 activates PR1 transcription by combining with TGA factors following the transfer to the nucleus [33], as detailed in this section.

\subsection{Role of NPR1 in Plant Immunity}

Plant evolution involves continuous improvement and sophistication of immune systems. As has been talked above (2.2), NPR1 shows defects in SA-mediated pathogen resistance on Arabidopsis mutants when it was first discovered; studies during the past two decades have clarified the role of NPR1 as a key transcriptional regulator affecting a wide variety of host genes involved in immune responses and biocompatibility $[27,109,114]$. This concept is supported by NPR1 overexpression experiments in A. thaliana. The conserved function of NPR1 has also been demonstrated in crop species such as rice, wheat, tomato, and apple [115]. Overexpression experiments with Arabidopsis NPR1 (AtNPR1) homologues [116] in these species have revealed powerful resistance against fungal and bacterial pathogen attacks [117-119].

Two-hybrid screening studies of a yeast model have shown that NPR1 interacts with TGA transcription factors through its ankyrin repeat domain [120], and also acts as a transcription co-activator to regulate SAR gene expression. SA-mediated activation of $P R$ genes is required for binding activity of NPR1 and TGA transcription factors to promoter elements [121,122]. TGA/OBF family members containing bZIP can also interact with NPR1 [120,121,123,124]. Following the binding of essential transcription factors to as- 1 component, the $P R$ gene promoter begins transcription and expression to initiate hypersensitive responses. NPR1 clearly functions as a key positive regulator in SA signaling, as well as a negative regulator in JA signaling [113].

\subsection{Transfer of NPR1 Degradation Products to Nucleus}

Under anti-pathogen defense response or SA induction, NPR1 is converted into monomers, which can be combined with TGA2 transcription factor to promote $P R$ gene expression, and are released (transferred) from cytoplasmic sites to the nucleus (Figure 1) [24,25,70,99,125].

NPR1 negatively regulates programmed cell death. Occurrence of ETI in pathogen-infected cells leads to high SA accumulation, followed by NPR1 regulation of its target genes, CUL/ NPR3-mediated NPR1 turnover, and activation of cell death. CUL3/ NPR4-mediated degradation of NPR1 around infected cells is necessary to avoid unnecessary activation of resistance [70]. This event must occur prior to NPR1 regulation of its target genes, because NPR1 is a negative regulator of cell death by CUL3/ NPR4. Cys156 is the essential amino acid residue for NPR1 oligomerization. NPR1 can be assembled into a high-molecular weight oligomer in cytoplasm through S-nitrosylation among its Cys156 residues [126,127]. S-nitrosoglutathione (GSNO) facilitates Cys156 disulfide bonding and promotes NPR1 oligomer formation (Figure 1). Following SAR induction, oligomers in cytoplasm 
release large amounts of NPR1 monomers which are transferred to the nucleus and subsequently turned over [128].

NPR1 monomer is preferentially degraded relative to NPR1 oligomer, and in 35S::NPR1-GFP plants, NPR1-GFP oligomer's being converted to monomer is accelerated [70,102,128]. In the absence of new protein synthesis, the NPR1-GFP level is reduced or unchanged. In the presence of dexamethasone (DEX), it promotes nuclear translocation of a NPR1 fused to a DEX-responsive glucocorticoid receptor (NPR1-GR) and rapidly degraded [102,128]. In the absence of DEX, NPR1-GR stays localized mainly in cytoplasm. Constitutive degradation of the NPR1 monomer by proteasomes occurs only in the nucleus [128].

\subsection{Differences between Systemic Acquired Resistance (SAR)-Induced and SAR-Uninduced Cells}

NPR1 is a key regulator of the SA-signaling network during SAR development. Although SAR has important functions in plant immunity, preventing untimely SAR activation is essential for normal growth and development. CUL3-mediated degradation of NPR1 monomer prevents SAR activation in plants not under pathogen challenge [128]. In SA treatment experiments with 35S::NPR1-GFP plants, NPR1 Ser11/15 phosphorylation level was greatly increased in SA-treated plants, whereas nuclear levels of phosphorylated endogenous NPR1 and NPR1-GFP were low in SA-nontreated plants. Turnover of phosphorylated NPR1 is essential for activation of SAR, and unphosphorylated NPR1 may be degraded in combination with target gene promoters. Gene transcription may be restricted by proteasomes, as a result of the destruction of transcription factors or proteolysis of co-activators, to protect assembly and installation of active transcription complexes [128]. Once the proteasome mediates NPR1 degradation, that SAR will respond stronger but more transiently [43].

\subsection{Role of NPR1 in Circadian Clock Core Loop}

NPR1 monomer level has recently been shown to peak at night, suggesting that rhythmic translocation of NPR1 to nucleus, controlled by rhythmic oscillation of endogenous SA, may regulate circadian clock genes. NPR1 antagonistics both SA and P. syringae infection in the regulation of circadian rhythms. The amplitude reduction and phase delay triggered by a transient SA treatment is prevented by NPR1, the amplitude reduction induced by Pst DC3000 infection was also enhanced in npr1-1 mutant plants [83]. NPR1 may function as an intrinsic regulator of clock gene TOC1 in response to rhythmic accumulation of endogenous SA [69]. NPR1 is most likely not the only regulator of TOC1. Treatment with $1 \mathrm{mM} \mathrm{SA}$ on 3-week-old soil-grown wild-type or on NPR1-3 mutant plants does not significantly alter the rhythm cycle. TOC1 expression level is increased immediately by SA induction [42]. Reduction of TOC1 level shortens the rhythm cycle, whereas increase of the TOC1 level lengthens the cycle $[71,129]$. Other clock genes such as $L H Y$, in contrast to TOC1, are sensitive to SA induction. The regulatory mechanism of clock genes in relation to plant immunity was elucidated by experiments using LHYp:LUC reporter (LHYp (TBSm):LUC). LHY expression peaked at dawn, while TOC1 expression was delayed by SA treatment, because LHY is an antagonist of TOC1 in the clock. NPR1 will strengthen the circadian clock when the redox rhythm is disrupted by challenges, through regulation of both morning-phased LHY and evening-phased TOC1 [69].

\section{Plant Immunity and Redox Rhythm as Related to the Circadian Clock}

Redox rhythm is closely associated with plant immunity, and both are related to the circadian clock. Early studies of the fungus Neurospora crassa suggested regulation of cellular redox state by the circadian clock [130]. Daily timekeeping functions are driven by both transcription-translation feedback loops (circadian clock) and non-transcriptional redox oscillations in numerous organisms, including Arabidopsis [2-4]. Nicotinamide adenine dinucleotide oxidation state (NAD/NADH ratio) also presents a daily rhythm. 


\subsection{Reactive Oxygen Species (ROS) Oscillation Triggers Plant Immunity}

The alteration of cellular redox state is one of the earliest occurring responses in a challenged cell [131]. ROS (e.g., $\mathrm{H}_{2} \mathrm{O}_{2}$ ) and reactive nitrogen species (RNS; e.g., nitric oxide [NO]) have closely related roles in plant immunity [132-134]. Plant immune responses are effectively triggered only if ROS and RNS signaling are activated simultaneously. The balance between ROS and RNS production is crucial in determining the fate of infected cells, and the success of plant immune responses [133,135].

Morning-phased CCA1 controls ROS homeostasis by regulating expression of catalases (e.g., catalase mutant $C A T 2$ ) involved in plant defense, Alvina et. al., pointed that CCA1 is a master regulator of ROS homeostasis (Figure 2) [35]. In Arabidopsis, inhibition of CAT2 activity by SA leads to increased $\mathrm{H}_{2} \mathrm{O}_{2}$ level (Figure 2) and subsequent sulfenylation (oxidation of thiol -SH into sulfenic acid -SOH) of tryptophan synthetase $\beta$-subunit 1 (TSB1) [136]. In contrast to historical and multigenerational circadian clocks based on differing transcription-translation feedback loops, the peroxiredoxin active site (responsible for redox rhythms) is conserved in a wide variety of organisms, indicating a possible origin of redox-based circadian clocks $[2,96]$.

\section{Interfere with plant growth and development}

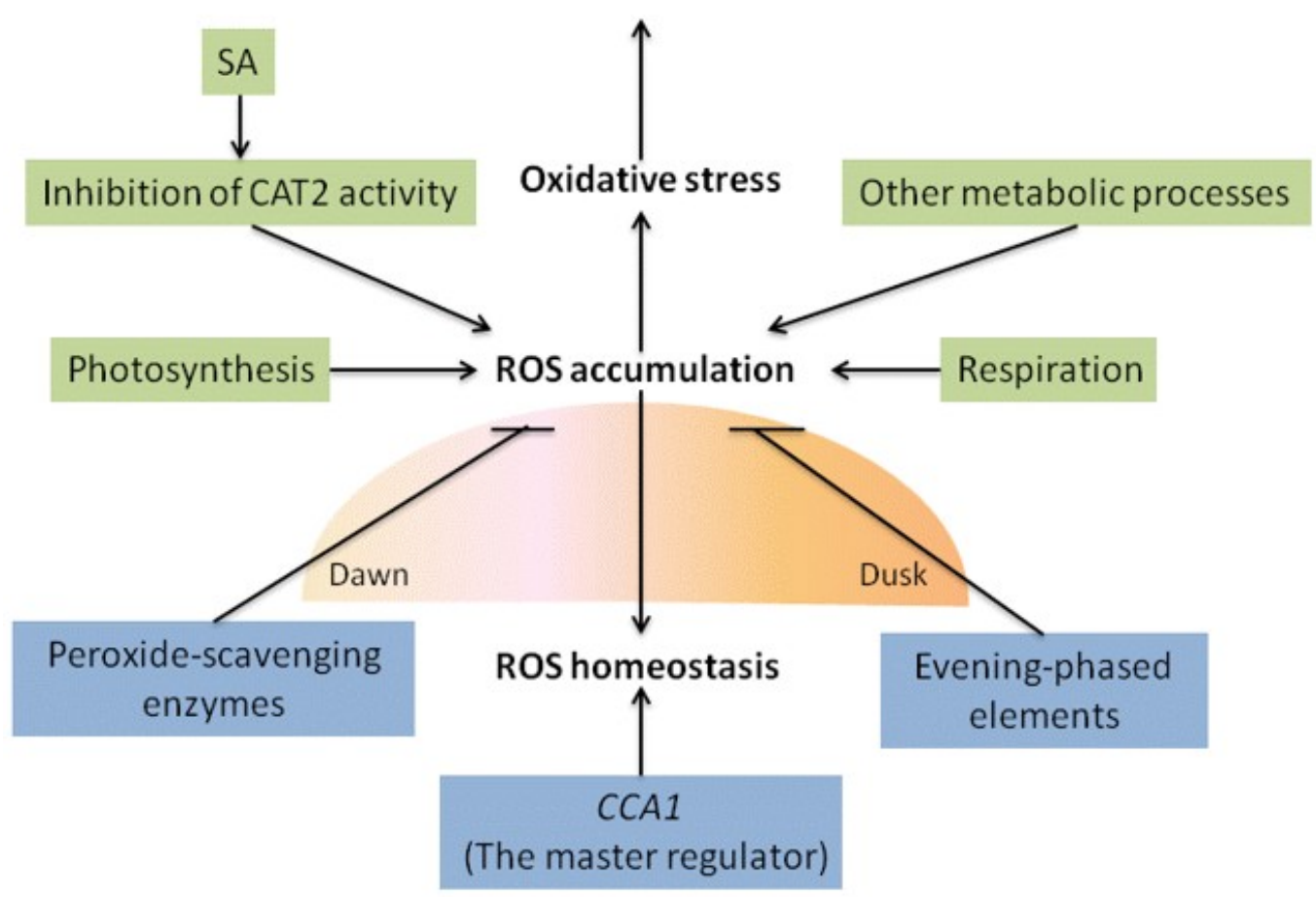

Figure 2. Reactive oxygen species (ROS) homeostasis. ROS, which are generated during photosynthesis, respiration, and other metabolic processes, peak around midday and are toxic to interfere with plant growth and development. CCA1 is a master regulator of ROS homeostasis. In Arabidopsis, inhibition of CAT2 activity by SA leads to increased $\mathrm{H}_{2} \mathrm{O}_{2}$ level. Oscillation of peroxide-scavenging enzyme levels is upregulated close to subjective dawn and inhibits ROS production. Evening-phased elements in promoters of antioxidant genes involved in transcriptional regulation were found to mitigate oxidative stress.

ROS, which are generated during photosynthesis, respiration, and other metabolic processes, and peak around midday, are toxic and can interfere with plant growth and development (Figure 2). In association with plant physiological responses, the level of redox species (which scavenge ROS) peaks at around the same time. Oscillation of peroxide-scavenging enzyme (antioxidant) levels is upregulated close to subjective dawn (Figure 2). ROS production can be inhibited by peroxide-scavenging enzymes (Figure 2). Circadian clock may, therefore, regulate ROS-related genes 
to prevent changes in ROS homeostasis $[137,138]$. Experiments on an Arabidopsis model to test the hypothesis that the antioxidant network is regulated by the circadian clock at the transcriptional level revealed that the ROS homeostasis regulon transcription was altered in CCA1 and LHY mutants. Evening-phased elements in promoters of antioxidant genes involved in transcriptional regulation were found to mitigate oxidative stress (Figure 2). These findings support the concept that central oscillators control oxidative stress through transcriptional regulation $[35,139]$.

\subsection{NADP/NADPH Oscillation Reflects Redox Rhythm}

Circadian redox rhythm in anucleate red blood cells (erythrocytes) is reflected in oscillations of both oxidation state of ROS scavenger peroxiredoxins and NADP/NADPH levels, both of which lack transcription/translation activities [3,96]. Redox rhythm is reflected mainly in regular changes of redox coenzymes NADPH and NADP ${ }^{+}$. Zhou et al. [42] found that, under constant light, NADPH peaked before subjective dawn while $\mathrm{NADP}^{+}$peaked before subjective dusk. Redox rhythm was sensitive to external perturbation; e.g., SA treatment disrupted NADPH/NADP ${ }^{+}$rhythms and altered their proportions to induce expression of defense-related genes.

\subsection{Oscillation of NPR1 Regulation Pathway}

Because the redox rhythm is regulated by NPR1, circadian redox rhythm in plants is coupled with a genetic clock. This coupling is mediated by cellular redox changes induced by endogenous SA level, which induce degradation and rhythmic nuclear translocation of NPR1 [69,70]. Endogenous SA levels oscillate in a circadian pattern [69]. Reduction by SA and glutathione of ethyl ester (GSHmee), a redox-altering reagent, enhanced expression of evening-phased TOC1 in an NPR1-dependent manner [140]. NPR1 is a general redox sensor that modulates clock gene TOC1. NPR1 monomer level peaks at night and displays a circadian oscillation pattern. Basal expression of TOC1 was reduced in both an NPR1 mutant and in an SA mutant [100]. Supplemental SA increased TOC1 expression in the SA mutant but not in the NPR1 mutant, regardless of treatment duration [42].

Redox signaling in plants helps determine the most suitable defense against pathogen infection, and the circadian clock helps predict various potential/ imminent attackers [132,141,142]. Upon pathogen challenge in Arabidopsis, stomatal closure is induced by NADPH oxidase RESPIRATORY BURST OXIDASE HOMOLOGUE D (RBOHD) [143,144]. SA accumulation is induced by RBOHF, another NADPH oxidase [145]. Expression of SA-dependent defense genes is induced by ROS produced by apoplastic peroxidases PRX33 and PRX34 [146-149]. Both stomatal closure and defense gene induction required NO, produced by NO synthase-like activity [96,150-152]. NO functions as a redox regulator to promote rhythmic nuclear translocation of NPR1, and thus plays an important role in the modulation of plant immunity [153].

Reduced glutathione (GSH) and oxidized glutathione (GSSG) form an essential antioxidant buffer system. Reduction of the GSH/GSSG ratio during pathogen infection leads to increased oxidative stress. NPR1 reduction does not lead to an immediate increase of the GSH/GSSG ratio [70]. GSH is, therefore, not a direct reducing agent of NPR1, although it has some correlation with redox changes of NPR1 and GSH/GSSG ratio. Other redox-related molecules such as glutathione and thioredoxin may be involved in NPR1 reduction. Pathogen challenge creates an SA gradient which is associated with changes in cellular redox and reduces the activity of two cytosolic thioredoxins (TRX-3h, TRX-5h) that catalyze monomerization of NPR1 and prevent its repolymerization (Figure 1) [126].

\section{Future Prospects}

We have summarized here a variety of evidence for connections between circadian clock, plant immunity, and redox rhythm. Cellular redox state is regulated by circadian clock. SA treatment of plants disrupted oscillations of $\mathrm{NADPH} / \mathrm{NADP}^{+}$and altered their proportions, thereby triggering expression of defense-related genes. ROS have a toxic (biocidal) effect on invading bacteria, but can also injure host cells. NPR1 may be the core element that links together the circadian clock and 
redox rhythm. Plant defense systems are associated with the circadian clock for regulation of daily physical activity via a complex network system. Defense responses create an environment conducive to plant survival, but often lead to growth inhibition, thus setting up a perpetual competition for resource allocation. Our understanding of plant immunity and the circadian clock has undergone major, sequential progress during the past decade, and research in both areas is well advanced. On the other hand, SA is the last of the major plant hormones whose receptors have an intricate control of SA responses. Future studies will further elucidate the mechanism of how SA receptors regulate plant defense responses and the core elements that coordinate the circadian clock with plant immunity.

Author Contributions: Conceptualization, J.Z., Z.R. and Y.Z.; writing-original draft preparation, J.Z., Z.M., and Y.M.; writing-review and editing, D.H. and X.H.; supervision, Z.X.

Funding: This study was supported by grants from the National Natural Science Foundation of China (31300223, 31572665), Natural Science Foundation of Shaanxi Province (2016JM3001), Opening Foundation of Key Laboratory of Resource Biology and Biotechnology in Western China (Northwest University), Ministry of Education, Key Scientific Research Project of Provincial Education Department of Shaanxi (15JS110, 15JS111), First-class University and Academic programs of Northwest University, and Training Programs of Innovation and Entrepreneurship for Undergraduates (Northwest University; 2018288).

Acknowledgments: The authors are grateful to S. Anderson for English editing of the manuscript.

Conflicts of Interest: The authors declare no conflict of interest. The funders had no role in the design of the study; in the collection, analyses, or interpretation of data; in the writing of the manuscript, or in the decision to publish the results.

\section{References}

1. Chi-Castañeda, D.; Ortega, A. Glial cells in the genesis and regulation of circadian rhythms. Front. Physiol. 2018, 9, 88-98.

2. Edgar, R.S.; Green, E.W.; Zhao, Y.; van Ooijen, G.; Olmedo, M.; Qin, X.; Xu, Y.; Pan, M.; Valekunja, U.K.; Feeney, K.A.; et al. Peroxiredoxins are conserved markers of circadian rhythms. Nature 2012, 485, 459-464. [CrossRef] [PubMed]

3. O'Neill, J.S.; Reddy, A.B. Circadian clocks in human red blood cells. Nature 2011, 469, 498-503. [CrossRef] [PubMed]

4. O'Neill, J.S.; Van Ooijen, G.; Dixon, L.E.; Troein, C.; Corellou, F.; Bouget, F.Y.; Reddy, A.B.; Millar, A.J. Circadian rhythms persist without transcription in a eukaryote. Nature 2011, 469, 554-558. [CrossRef] [PubMed]

5. Wright, K.P.; McHill, A.W.; Birks, B.R.; Griffin, B.; Rusterholz, R.T.; Chinoy, E.D. Entrainment of the human circadian clock to the natural light-dark cycle. Curr. Biol. 2013, 23, 1554-1558. [CrossRef] [PubMed]

6. Greenham, K.; Mcclung, C.R. Integrating circadian dynamics with physiological processes in plants. Nat. Rev. Genet. 2015, 16, 598-610. [CrossRef] [PubMed]

7. Hemmes, H.; Henriques, R.; Jang, I.C.; Kim, S.; Chua, N.H. Circadian clock regulates dynamic chromatin modifications associated with Arabidopsis CCA1/LHY and TOC1 transcriptional rhythms. Plant Cell Physiol. 2012, 53, 2016-2029. [CrossRef] [PubMed]

8. Hsu, P.Y.; Harmer, S.L. Wheels within wheels: The plant circadian system. Trends Plant Sci. 2014, 19, $240-249$. [CrossRef] [PubMed]

9. Mcclung, C.R. The genetics of plant clocks. Adv Genet. 2011, 74, 105-139. [PubMed]

10. Ingle, R.A.; Roden, L.C. Circadian regulation of plant immunity to pathogens. Methods Mol. Biol. 2014, 1158, 273-283. [PubMed]

11. Bolouri Moghaddam, M.R.; Van den, E.W. Sweet immunity in the plant circadian regulatory network. J. Exp. Bot. 2013, 64, 1439-1449. [CrossRef] [PubMed]

12. Korneli, C.; Danisman, S.; Staiger, D. Differential control of pre-invasive and post-invasive antibacterial defense by the Arabidopsis circadian clock. Plant Cell Physiol. 2014, 55, 1613-1622. [CrossRef] [PubMed]

13. Dodd, A.; Salathia, N.; Hall, A.; Kevei, E.; Toth, R.; Nagy, F.; Hibberd, J.M.; Millar, A.J.; Webb, A.A. Plant circadian clocks increase photosynthesis, growth, survival, and competitive advantage. Science 2005, 309, 630-633. [CrossRef] [PubMed] 
14. Michael, T.P.; Salomé, P.A.; Yu, H.J.; Spencer, T.R.; Sharp, E.L.; McPeek, M.A.; Alonso, J.M.; Ecker, J.R.; McClung, C.R. Enhanced fitness conferred by naturally occurring variation in the circadian clock. Science 2003, 302, 1049-1053. [CrossRef] [PubMed]

15. Torres, M.; Becquet, D.; Franc, J.L.; François-Bellan, A.M. Circadian processes in the RNA life cycle. Wiley Interdiscip. Rev. RNA 2018, 9, e1467. [CrossRef] [PubMed]

16. Eggermont, K.; Mauch-Mani, B.; Vogelsang, R.; Broekaert, W.F. Separate jasmonate-dependent and salicylate-dependent defense-response pathways in Arabidopsis are essential for resistance to distinct microbial pathogens. Proc. Natl. Acad. Sci. USA 1998, 95, 15107-15111.

17. Fabro, G.; Di, R.J.; Voigt, C.A.; Savchenko, T.; Dehesh, T.K.; Somerville, S.; Alvarez, M.E. Genome-wide expression profiling Arabidopsis at the stage of Golovinomyces cichoracearum haustorium formation. Plant Physiol. 2008, 146, 1421-1439. [CrossRef] [PubMed]

18. Murray, S.L.; Ingle, R.A.; Petersen, L.N.; Denby, K.J. Basal resistance against Pseudomonas syringae in Arabidopsis involves WRKY53 and a protein with homology to a nematode resistance protein. Mol. Plant Microbe Interact. 2007, 20, 1431-1438. [CrossRef] [PubMed]

19. Li, L.; Yu, Y.; Zhou, Z.; Zhou, J.M. Plant pattern-recognition receptors controlling innate immunity. Sci. China Life Sci. 2016, 59, 878-888. [CrossRef] [PubMed]

20. Gheysen, G.; Mitchum, M.G. How nematodes manipulate plant development pathways for infection. Curr. Opin. Plant Biol. 2011, 14, 415-421. [CrossRef] [PubMed]

21. Erb, M.; Meldau, S.; Howe, G.A. Role of phytohormones in insect-specific plant reactions. Trends Plant Sci. 2012, 17, 250-259. [CrossRef] [PubMed]

22. Dodds, P.N.; Rathjen, J.P. Plant immunity: Towards an integrated view of plant-pathogen interactions. Nat. Rev. Genet. 2010, 11, 539-548. [CrossRef] [PubMed]

23. Rate, D.N.; Greenberg, J.T. The Arabidopsis aberrant growth and death 2 mutant shows resistance to Pseudomonas syringae and reveals a role for NPR1 in suppressing hypersensitive cell death. Plant J. 2001, 27, 203-211. [CrossRef] [PubMed]

24. Cao, H.; Bowling, S.A.; Gordon, A.S.; Dong, X. Characterization of an Arabidopsis mutant that is nonresponsive to inducers of systemic acquired resistance. Plant Cell 1994, 6, 1583-1592. [CrossRef] [PubMed]

25. Delaney, T.P.; Ryals, J.A. Arabidopsis signal transduction mutant defective in chemically and biologically induced disease resistance. Proc. Natl. Acad. Sci. USA 1995, 92, 6602-6606. [CrossRef] [PubMed]

26. Uknes, S.; Mauch-Mani, S.; Moyer, M.; Potter, S.; Williams, S.; Dincher, S.; Chandler, D.; Slusarenko, A.; Ward, E.; Ryals, J. Acquired resistance in Arabidopsis. Plant Cell 1992, 4, 645-656. [CrossRef] [PubMed]

27. Wang, D.; Weaver, N.D.; Kesarwani, M.; Dong, X. Induction of protein secretory pathway is required for systemic acquired resistance. Science 2005, 308, 1036-1040. [CrossRef] [PubMed]

28. Bari, R.; Jones, J.D.G. Role of plant hormones in plant defence responses. Plant Mol. Biol. 2009, 69, 473-488. [CrossRef] [PubMed]

29. Glazebrook, J. Contrasting mechanisms of defense against biotrophic and necrotrophic pathogens. Annu. Rev. Phytopathol. 2005, 43, 205-227. [CrossRef] [PubMed]

30. Jones, J.D.G.; Dangl, J.L. The plant immune system. Nature 2006, 444, 323-329. [CrossRef] [PubMed]

31. Pieterse, C.M.; Van der Does, D.; Zamioudis, C.; Leon-Reyes, A.; Van Wees, S.C. Hormonal modulation of plant immunity. Annu. Rev. Cell Dev. Biol. 2012, 28, 489-521. [CrossRef] [PubMed]

32. Robertseilaniantz, A.; Grant, M.; Jones, J.D.G. Hormone crosstalk in plant disease and defense: More than just jasmonate-salicylate antagonism. Annu. Rev. Phytopathol. 2011, 49, 317-343. [CrossRef] [PubMed]

33. Spoel, S.H.; Dong, X. How do plants achieve immunity? Defence without specialized immune cells. Nat. Rev. Immunol. 2012, 12, 89-100. [CrossRef] [PubMed]

34. Spoel, S.H.; Johnson, J.S.; Dong, X. Regulation of tradeoffs between plant defenses against pathogens with different lifestyles. Proc. Natl. Acad. Sci. USA 2007, 104, 18842-18847. [CrossRef] [PubMed]

35. Lai, A.G.; Doherty, C.J.; Muellerroeber, B.; Kay, S.A.; Schippers, J.H.; Dijkwel, P.P. CIRCADIAN CLOCK-ASSOCIATED 1 regulates ROS homeostasis and oxidative stress responses. Proc. Natl. Acad. Sci. USA 2012, 109, 17129-17134. [CrossRef] [PubMed]

36. Peek, C.B.; Affinati, A.H.; Ramsey, K.M.; Kuo, H.Y.; Yu, W.; Sena, L.A.; IlKayeva, O.; Marcheva, B.; Kobayashi, Y.; Omura, C.; et al. Circadian clock NAD ${ }^{+}$cycle drives mitochondrial oxidative metabolism in mice. Science 2013, 342, 591-607. [CrossRef] [PubMed] 
37. Ramsey, K.M.; Yoshino, J.; Brace, C.S.; Abrassart, D.; Kobayashi, Y.; Marcheva, B.; Hong, H.K.; Chong, J.L.; Buhr, E.D.; Lee, C.; et al. Circadian clock feedback cycle through nampt-mediated NAD ${ }^{+}$biosynthesis. Science 2009, 324, 651-654. [CrossRef] [PubMed]

38. Nürnberger, T.; Brunner, F.; Kemmerling, B.; Piater, L. Innate immunity in plants and animals: Striking similarities and obvious differences. Immunol. Rev. 2004, 198, 249-266. [CrossRef] [PubMed]

39. Elmayan, T.; Simon-Plas, F. Regulation of Plant NADPH Oxidase. Plant Signal Behav. 2007, 2, 505-507. [CrossRef] [PubMed]

40. Dong, X. NPR1, all things considered. Curr. Opin. Plant Biol. 2004, 7, 547-552. [CrossRef] [PubMed]

41. Kumar, D. Salicylic acid signaling in disease resistance. Plant Sci. 2014, 228, 127-134. [CrossRef] [PubMed]

42. Zhou, M.; Wei, W.; Kararpetyan, S.; Mwimba, M.; Marqués, J.; Buchler, N.E.; Dong, X. Redox rhythm reinforces the circadian clock to gate immune response. Nature 2015, 523, 472-476. [CrossRef] [PubMed]

43. Withers, J.; Dong, X. Posttranslational Modifications of NPR1: A single protein playing multiple roles in plant immunity and physiology. PLoS Pathog. 2016, 12, 1005707. [CrossRef] [PubMed]

44. Nagel, D.H.; Kay, S.A. Complexity in the wiring and regulation of plant circadian networks. Curr. Biol. 2012, 22, 648-657. [CrossRef] [PubMed]

45. Pokhilko, A.; Fernández, A.P.; Edwards, K.D.; Southern, M.M.; Halliday, K.J.; Millar, A.J. The clock gene circuit in Arabidopsis includes a repressilator with additional feedback loops. Mol. Syst. Biol. 2012, 8, 574-586. [CrossRef] [PubMed]

46. Roden, L.C.; Ingle, R.A. Lights, rhythms, infection: The role of light and the circadian clock in determining the outcome of plant-pathogen interactions. Plant Cell 2009, 21, 2546-2552. [CrossRef] [PubMed]

47. Wang, Z.Y.; Tobin, E.M. Constitutive expression of the CIRCADIAN CLOCK ASSOCIATED 1, (CCA1) gene disrupts circadian rhythms and suppresses its own expression. Cell 1998, 93, 1207-1217. [CrossRef]

48. Schaffer, R.; Ramsay, N.; Samach, A.; Corden, S.; Putterill, J.; Carrã, I.A.; Coupland, G. The LATE ELONGATED HYPOCOTYL mutation of Arabidopsis disrupts circadian rhythms and the photoperiodic control of flowering. Cell 1998, 93, 1219-1229. [CrossRef]

49. Farré, E.M.; Harmer, S.L.; Harmon, F.G.; Anovsky, M.J.; Kay, S.A. Overlapping and distinct roles of PRR7 and PRR9 in the Arabidopsis circadian clock. Curr. Biol. 2005, 15, 47-54. [CrossRef] [PubMed]

50. Nakamichi, N.; Kita, M.; Ito, S.; Sato, E.; Yamashino, T.; Mizuno, T. The Arabidopsis pseudo-response regulators, PRR5 and PRR7, coordinately play essential roles for circadian clock function. Plant Cell Physiol. 2005, 46, 609-619. [CrossRef] [PubMed]

51. Matsushika, A.; Makino, S.; Kojima, M.; Yamashino, T.; Mizuno, T. The a PRR1/TOC1 quintet implicated in circadian rhythms of Arabidopsis thaliana: II. characterization with CCA1-overexpressing plants. Plant Cell Physiol. 2002, 43, 118-122. [CrossRef] [PubMed]

52. Strayer, C.; Oyama, T.; Schultz, T.F.; Raman, R.; Somers, D.E.; Más, P.; Panda, S.; Kreps, J.A.; Kay, S.A. Cloning of the Arabidopsis clock gene TOC1, an autoregulatory response regulator homolog. Science 2000, 289, 768-771. [CrossRef] [PubMed]

53. Fujiwara, S.; Wang, L.; Han, L.; Suh, S.P.; Mcclung, C.; Somers, D. Post-translational regulation of the Arabidopsis circadian clock through selective proteolysis and phosphorylation of pseudo-response regulator proteins. J. Biol. Chem. 2008, 283, 23073-23083. [CrossRef] [PubMed]

54. Alabadí, D.; Oyama, T.; Yanovsky, M.J.; Harmon, F.G.; Más, P.; Kay, S.A. Reciprocal regulation between TOC1 and LHY /CCA1 within the Arabidopsis circadian clock. Science 2001, 293, 880-883. [CrossRef] [PubMed]

55. Imaizumi, T. Arabidopsis circadian clock and photoperiodism: Time to think about location. Curr. Opin. Plant Biol. 2010, 13, 83-89. [CrossRef] [PubMed]

56. Pruneda-Paz, J.L.; Kay, S.A. An expanding universe of circadian networks in higher plants. Trends Plant Sci. 2010, 15, 259-265. [CrossRef] [PubMed]

57. Fowler, S.; Lee, K.; Onouchi, H.; Samach, A.; Richardson, K.; Morris, B.; Coupland, G.; Putterill, J. Gigantea: A circadian clock-controlled gene that regulates photoperiodic flowering in Arabidopsis and encodes a protein with several possible membrane-spanning domains. EMBO J. 1999, 18, 4679-4688. [CrossRef] [PubMed]

58. Gendron, J.M.; Pruneda-Paz, J.L.; Doherty, C.J.; Gross, A.M.; Kang, S.E.; Kay, S.A. Arabidopsis circadian clock protein, TOC1, is a DNA-binding transcription factor. Proc. Natl. Acad. Sci. USA 2012, 109, 3167-3172. [CrossRef] [PubMed] 
59. Huang, W.; Pérezgarcía, P.; Pokhilko, A.; Millar, A.J.; Antoshechkin, I.; Riechmann, J.L.; Mas, P. Mapping the core of the Arabidopsis circadian clock defines the network structure of the oscillator. Science 2012, 336, 75-79. [CrossRef] [PubMed]

60. Green, R.M.; Tingay, S.; Wang, Z.Y.; Tobin, E.M. Circadian rhythms confer a higher level of fitness to Arabidopsis plants. Plant Physiol. 2002, 129, 576-584. [CrossRef] [PubMed]

61. Green, R.M.; Tobin, E.M. Loss of the circadian clock-associated protein 1 in Arabidopsis results in altered clock-regulated gene expression. Proc. Natl. Acad. Sci. USA 1999, 96, 4176-4179. [CrossRef] [PubMed]

62. Zhang, C.; Xie, Q.; Anderson, R.G.; Ng, G.; Seitz, N.C.; Peterson, T.; McClung, C.R.; McDowell, J.M.; Kong, D.; Kwak, J.M.; et al. Crosstalk between the circadian clock and innate immunity in Arabidopsis. PLoS Pathog. 2013, 9, e1003370. [CrossRef] [PubMed]

63. Somers, D.E.; Webb, A.A.; Pearson, M.; Kay, S.A. The short-period mutant, TOC1-1, alters circadian clock regulation of multiple outputs throughout development in Arabidopsis thaliana. Development 1998, 125, 485-494. [PubMed]

64. Wang, W.; Barnaby, J.Y.; Tada, Y.; Li, H.; Tör, M.; Caldelari, D.; Lee, D.U.; Fu, X.D.; Dong, X. Timing of plant immune responses by a central circadian regulator. Nature 2011, 470, 110-114. [CrossRef] [PubMed]

65. Zheng, X.Y.; Zhou, M.; Yoo, H.; Pruneda-Paz, J.L.; Spivey, N.W.; Kay, S.A.; Dong, X. Inaugural article by a recently elected academy member: Spatial and temporal regulation of biosynthesis of the plant immune signal salicylic acid. Proc. Natl. Acad. Sci. USA 2015, 112, 9166-9173. [CrossRef] [PubMed]

66. Hevia, M.A.; Canessa, P.; Müller-Esparza, H.; Larrondo, L.F. A circadian oscillator in the fungus Botrytis cinerea regulates virulence when infecting Arabidopsis thaliana. Pro Natl. Acad Sci. USA. 2015, 112, 8744-8749. [CrossRef] [PubMed]

67. Seo, P.J.; Mas, P. Stressing the role of the plant circadian clock. Trends Plant Sci. 2015, 20, 230-237. [CrossRef] [PubMed]

68. Ingle, R.A.; Stoker, C.; Stone, W.; Adams, N.; Denby, K.J. Jasmonate signalling drives time-of-day differences in susceptibility of Arabidopsis to the fungal pathogen Botrytis cinerea. Plant J. 2015, 84, 937-948. [CrossRef] [PubMed]

69. Goodspeed, D.; Chehab, E.W.; Minvenditti, A.; Braam, J.; Covington, M.F. From the cover: Arabidopsis synchronizes jasmonate-mediated defense with insect circadian behavior. Proc. Natl. Acad. Sci. USA 2012, 109, 4674-4677. [CrossRef] [PubMed]

70. Mou, Z.; Fan, W.; Dong, X. Inducers of plant systemic acquired resistance regulate NPR1 function through redox changes. Cell 2003, 113, 935-944. [CrossRef]

71. Millar, A.J.; Carre, I.A.; Strayer, C.A.; Chua, N.H.; Kay, S.A. Circadian clock mutants in Arabidopsis identified by luciferase imaging. Science 1995, 267, 1161-1163. [CrossRef] [PubMed]

72. Más, P.; Kim, W.Y.; Somers, D.E.; Kay, S.A. Targeted degradation of TOC1 by ZTL modulates circadian function in Arabidopsis thaliana. Nature 2003, 426, 567-570. [CrossRef] [PubMed]

73. Donofrio, N.M.; Delaney, T.P. Abnormal callose response phenotype and hypersusceptibility to Peronospoara parasitica in defence-compromised Arabidopsis NIM1-1 and salicylate hydroxylase-expressing plants. Mol. Plant Microbe Interact. 2001, 14, 439-450.

74. Ea, V.D.B.; Freddie, C.T.; Kahn, K.; Parker, J.E.; Jones, J.D. Arabidopsis RPP4 is a member the RPP5 multigene family of TIR-NB-LRR genes and confers downy mildew resistance through multiple signaling components. Plant J. 2002, 29, 439-451.

75. Salomé, P.A.; Mcclung, C.R. Pseudo-response regulator 7 and 9 are partially redundant genes essential for the temperature responsiveness of the arabidopsis circadian clock. Plant Cell 2005, 3, 791-803. [CrossRef] [PubMed]

76. Bhardwaj, V.; Meier, S.; Petersen, L.N.; Ingle, R.A.; Roden, L.C. Defence responses of Arabidopsis thaliana to infection by Pseudomonas syringae are regulated by the circadian clock. PLoS ONE 2011, 6, e26968. [CrossRef] [PubMed]

77. Hermanns, M.; Slusarenko, A.J.; Schlaich, N.L. Organ-specificity in a plant disease is determined independently of $R$ gene signaling. Mol. Plant Microbe Interact. 2003, 16, 752-759. [CrossRef] [PubMed]

78. Fu, Z.Q.; Guo, M.; Jeong, B.R.; Tian, F.; Elthon, T.E.; Cerny, R.L.; Staiger, D.; Alfano, J.R. A type III effector ADP-ribosylates RNA-binding proteins and quells plant immunity. Nature 2007, 447, 284-288. [CrossRef] [PubMed] 
79. Heintzen, C.; Nater, M.; Apel, K.; Staiger, D. AtGRP7, a nuclear RNA binding protein as a component of a circadian-regulated negative feedback loop in Arabidopsis thaliana. Proc. Natl. Acad. Sci. USA 1997, 94, 8515-8520. [CrossRef] [PubMed]

80. Staiger, D.; Zecca, L.; Wieczorek Kirk, D.A.; Apel, K.; Eckstein, L. The circadian clock regulated RNA-binding protein AtGRP7 autoregulates its expression by influencing alternative splicing of its own pre-mRNA. Plant J. 2003, 33, 361-371. [CrossRef] [PubMed]

81. Niwa, Y.; Ito, S.; Nakamichi, N.; Mizoguchi, T.; Niinuma, K.; Yamashino, T.; Mizuno, T. Genetic linkages of the circadian clock-associated genes, TOC1, CCA1 and LHY, in the photoperiodic control of flowering time in Arabidopsis thaliana. Plant Cell Physiol. 2007, 48, 925-937. [CrossRef] [PubMed]

82. Ederli, L.; Madeo, L.; Calderini, O.; Gehring, C.; Moretti, C.; Buonaurio, R.; Paolocci, F.; Pasqualini, S. The Arabidopsis thaliana cysteine-rich receptor-like kinase CRK20 modulates host responses to Pseudomonas syringae pv. tomato DC3000 infection. J. Plant Physiol. 2011, 15, 1784-1794. [CrossRef] [PubMed]

83. Li, Z.; Bonaldi, K.; Uribe, F.; Pruneda-Paz, J.L. A localized pseudomonas syringae, infection triggers systemic clock responses in Arabidopsis. Curr. Biol. 2018, 4, 28-42. [CrossRef] [PubMed]

84. Fu, Z.Q.; Yan, S.; Saleh, A.; Wang, W.; Ruble, J.; Oka, N.; Mohan, R.; Spoel, S.H.; Tada, Y.; Zheng, N.; et al. NPR3 and NPR4 are receptors for the immune signal salicylic acid in plants. Nature 2012, 486, 228-232. [CrossRef] [PubMed]

85. Carella, P.; Wilson, D.C.; Cameron, R.K. Some things get better with age: Differences in salicylic acid accumulation and defense signaling in young and mature Arabidopsis. Front Plant Sci. 2015, 5, 775. [CrossRef] [PubMed]

86. Nagel, D.H.; Doherty, C.J.; Pruneda-Paz, J.L.; Schmitz, R.J.; Ecker, J.R.; Kay, S.A. Genome-wide identification of CCA1 targets uncovers an expanded clock network in Arabidopsis. Proc. Natl. Acad. Sci. USA 2015, 112, 4802-4810. [CrossRef] [PubMed]

87. Shin, J.; Heidrich, K.; Sanchez-Villarreal, A.; Parker, J.E.; Davis, S.J. Time for coffee represses accumulation of the MYC2 transcription factor to provide time-of-day regulation of jasmonate signaling in Arabidopsis. Plant Cell 2012, 24, 2470-2482. [CrossRef] [PubMed]

88. Wu, Y.; Zhang, D.; Chu, J.Y.; Boyle, P.; Wang, Y.; Brindle, I.; De Luca, V.; Després, C. The Arabidopsis, NPR1 protein is a receptor for the plant defense hormone salicylic acid. Cell Rep. 2012, 1, 639-647. [CrossRef] [PubMed]

89. Yan, S.; Dong, X. Perception of the plant immune signal salicylic acid. Curr. Opin. Plant Biol. 2014, 20, 64-68. [CrossRef] [PubMed]

90. Liu, T.; Carlsson, J.; Takeuchi, T.; Newton, L.; Farré, E.M. Direct regulation of abiotic responses by the Arabidopsis circadian clock component PRR7. Plant J. 2013, 76, 101-114. [CrossRef] [PubMed]

91. Liu, T.L.; Newton, L.; Liu, M.J.; Shiu, S.H.; Farré, E.M. A G-box-like motif is necessary for transcriptional regulation by circadian pseudo-response regulators in Arabidopsis. Plant Physiol. 2016, 170, 528-539. [CrossRef] [PubMed]

92. Nakamichi, N.; Kiba, T.; Kamioka, M.; Suzuki, T.; Yamashino, T.; Higashiyama, T.; Sakakibara, H.; Mizuno, T. Transcriptional repressor PRR5 directly regulates clock-output pathways. Proc. Natl. Acad. Sci. USA 2012, 109, 17123-17128. [CrossRef] [PubMed]

93. Atamian, H.S.; Harmer, S.L. Circadian regulation of hormone signaling and plant physiology. Plant Mol. Biol. 2016, 91, 691-702. [CrossRef] [PubMed]

94. Baldwin, I.T.; Meldau, S. Just in time: Circadian defense patterns and the optimal defense hypothesis. Plant Signal Behav. 2013, 8, e24410. [CrossRef] [PubMed]

95. Wang, G.; Zhang, C.; Battle, S.; Lu, H. The phosphate transporter PHT4;1 is a salicylic acid regulator likely controlled by the circadian clock protein CCA1. Front Plant Sci. 2014, 5, 701-710. [CrossRef] [PubMed]

96. Karapetyan, S.; Dong, X. Redox and the circadian clock in plant immunity: A balancing act. Free Radic. Biol. Med. 2017, 10, e1044192. [CrossRef] [PubMed]

97. Ding, Y.; Sun, T.; Ao, K.; Peng, Y.; Zhang, Y.; Li, X.; Zhang, Y. Opposite roles of salicylic acid receptors NPR1 and NPR3/NPR4 in transcriptional regulation of plant immunity. Cell 2018, 6, 173-203. [CrossRef] [PubMed]

98. Glazebrook, J.; Rogers, E.E.; Ausubel, F.M. Isolation of Arabidopsis mutants with enhanced disease susceptibility by direct screening. Genetics 1996, 143, 973-982. [PubMed] 
99. Shah, J.; Tsui, F.; Klessig, D.F. Characterization of a salicylic acid-insensitive mutant (SAI1) of Arabidopsis thaliana, identified in a selective screen utilizing the SA-inducible expression of the TMS2 gene. Mol. Plant Microbe Interact. 1997, 10, 69-78. [CrossRef] [PubMed]

100. Cao, H.; Glazebrook, J.; Clarke, J.D.; Volko, S.; Dong, X. The Arabidopsis NPR1 gene that controls systemic acquired resistance encodes a novel protein containing ankyrin repeats. Cell 1997, 88, 57-63. [CrossRef]

101. Aravind, L.; Koonin, E.V. Fold prediction and evolutionary analysis of the POZ domain: Structural and evolutionary relationship with the potassium channel tetramerization domain. J. Mol. Biol. 1999, 285, 1353-1361. [CrossRef] [PubMed]

102. Kinkema, M.; Fan, W.; Dong, X. Nuclear localization of NPR1 is required for activation of PR gene expression. Plant Cell 2000, 12, 2339-2350. [CrossRef] [PubMed]

103. Petroski, M.D.; Deshaies, R.J. Function and regulation of cullin-RING ubiquitin ligases. Nat. Rev. Mol. Cell Biol. 2005, 6, 9-20. [CrossRef] [PubMed]

104. Durrant, W.E.; Dong, X. Systemic acquired resistance. Annu. Rev. Phytopathol. 2004, 42, 185-209. [CrossRef] [PubMed]

105. Rodriguez, S.C.; López, B.; Chaves, A.R. Changes in polyamines and ethylene during the development and ripening of eggplant fruits (solanum melongena). J. Agric. Food Chem. 1999, 47, 1431-1434. [CrossRef] [PubMed]

106. Luke-Glaser, S.; Pintard, L.; Tyers, M.; Peter, M. The AAA-ATPase FIGL-1 controls mitotic progression, and its levels are regulated by the CUL-3 ${ }^{\mathrm{MEL}-26}$ E3 ligase in the C. elegans germ line. J. Cell Sci. 2007, 120, 3179-3187. [CrossRef] [PubMed]

107. Pintard, L.; Willems, A.; Peter, M. Cullin-based ubiquitin ligases: Cul3-BTB complexes join the family. EMBO J. 2004, 23, 1681-1687. [CrossRef] [PubMed]

108. Pintard, L.; Willis, J.H.; Willems, A.; Johnson, J.L.; Srayko, M.; Kurz, T.; Glaser, S.; Mains, P.E.; Tyers, M.; Bowerman, B.; et al. The BTB protein MEL-26 is a substrate-specific adaptor of the CUL-3 ubiquitin-ligase. Nature 2003, 425, 311-316. [CrossRef] [PubMed]

109. Mukhtar, M.S.; Nishimura, M.T.; Dangl, J. NPR1 in plant defense: it's not over 'til it's turned over. Cell 2009, 137, 804-806. [CrossRef] [PubMed]

110. Zhang, Y.; Yu, T.C.; Na, Q.; Zhao, Q.; Bi, D.; Xin, L. Negative regulation of defense responses in Arabidopsis by two NPR1 paralogs. Plant J. 2006, 48, 647-656. [CrossRef] [PubMed]

111. Manohar, M.; Tian, M.; Moreau, M.; Park, S.W.; Choi, H.W.; Fei, Z.; Friso, G.; Asif, M.; Manosalva, P.; Von Dahl, C.C.; et al. Identification of multiple salicylic acid-binding proteins using two high throughput screens. Front Plant Sci. 2015, 5, 777-791. [CrossRef] [PubMed]

112. Enyedi, A.J.; Yalpani, N.; Silverman, P.; Raskin, I. Localization, conjugation, and function of salicylic acid in tobacco during the hypersensitive reaction to tobacco mosaic virus. Proc. Natl. Acad. Sci. USA 1992, 89, 2480-2484. [CrossRef] [PubMed]

113. Spoel, S.H.; Koornneef, A.; Claessens, S.M.; Korzelius, J.P.; Pelt, J.A.; Mueller, M.J.; Buchala, A.J.; Métraux, J.; Brown, R.; Kazan, K.; et al. NPR1 modulates cross-talk between salicylate- and jasmonate-dependent defense pathways through a novel function in the cytosol. Plant Cell 2003, 15, 760-770. [CrossRef] [PubMed]

114. Heidel, A.J.; Dong, X. Fitness benefits of systemic acquired resistance during Hyaloperonospora parasitica infection in Arabidopsis thaliana. Genetics 2006, 173, 1621-1628. [CrossRef] [PubMed]

115. Fu, Z.Q.; Dong, X. Systemic acquired resistance: Turning local infection into global defense. Annu. Rev. Plant Biol. 2013, 64, 839-863. [CrossRef] [PubMed]

116. Cao, H.; Li, X.; Dong, X. Generation of broad-spectrum disease resistance by overexpression of an essential regulatory gene in systemic acquired resistance. Proc. Natl. Acad. Sci. USA 1998, 95, 6531-6536. [CrossRef] [PubMed]

117. Chern, M.S.; Fitzgerald, H.A.; Yadav, R.C.; Canlas, P.E.; Dong, X.; Ronald, P.C. Evidence for a disease-resistance pathway in rice similar to the NPR1-mediated signaling pathway in Arabidopsis. Plant J. 2001, 27, 101-113. [CrossRef] [PubMed]

118. Makandar, R.; Essig, J.S.; Schapaugh, M.A.; Trick, H.N.; Shah, J. Genetically engineered resistance to fusarium head blight in wheat by expression of Arabidopsis NPR1. Mol. Plant Microbe Interact. 2006, 19, 123-129. [CrossRef] [PubMed] 
119. Malnoy, M.; Jin, Q.; Borejsza-Wysocka, E.E.; He, S.Y.; Aldwinckle, H.S. Overexpression of the apple MpNPR1 gene confers increased disease resistance in Malus $\times$ domestica. Mol. Plant Microbe Interact. 2007, 20, 1568-1580. [CrossRef] [PubMed]

120. Zhou, J.M.; Trifa, Y.; Silva, H.; Pontier, D.; Lam, E.; Shah, J.; Klessing, D.F. NPR1 differentially interacts with members of the TGA/OBF family of transcription factors that bind an element of the PR-1 gene required for induction by salicylic acid. Mol. Plant Microbe Interact. 2000, 13, 191-202. [CrossRef] [PubMed]

121. Després, C.; Delong, C.; Glaze, S.; Liu, E.W.; Fobert, P.R. The Arabidopsis NPR1/NIM1 protein enhances the DNA binding activity of a subgroup of the TGA family of bZIP transcription factors. Plant Cell 2000, 12, 279-290. [CrossRef] [PubMed]

122. Fan, W.; Dong, X. In vivo interaction between NPR1 and transcription factor TGA2 leads to salicylic acid-mediated gene activation in Arabidopsis. Plant Cell 2002, 14, 1377-1389. [CrossRef] [PubMed]

123. Zhang, Y.; Fan, W.; Kinkema, M.; Li, X.; Dong, X. Interaction of NPR1 with basic leucine zipper protein transcription factors that bind sequences required for salicylic acid induction of the PR-1 gene. Proc. Natl. Acad. Sci. USA 1999, 96, 6523-6528. [CrossRef] [PubMed]

124. Subramaniam, R.; Desveaux, D.; Spickler, C.; Michnick, S.W.; Brisson, N. Direct visualization of protein interactions in plant cells. Nat. Biotechnol. 2001, 19, 769-772. [CrossRef] [PubMed]

125. Ryals, J.; Weymann, K.; Lawton, K.; Friedrich, L.; Ellis, D.; Steiner, H.Y.; Johnson, J.; Delaney, T.P.; Jesse, T.; Vos, P.; et al. The Arabidopsis NIM1 protein shows homology to the mammalian transcription factor inhibitor i kappa B. Plant Cell 1997, 9, 425-439. [CrossRef] [PubMed]

126. Tada, Y.; Spoel, S.H.; Pajerowska-Mukhtar, K.; Mou, Z.; Song, J.; Wang, C.; Zuo, J.; Dong, X. Plant immunity requires conformational changes of NPR1 via S-nitrosylation and thioredoxins. Science 2008, 321, 952-956. [CrossRef] [PubMed]

127. Spoel, S.H.; Tada, Y.; Loake, G.J. Post-translational protein modification as a tool for transcription reprogramming. New Phytol. 2010, 186, 333-339. [CrossRef] [PubMed]

128. Spoel, S.H.; Mou, Z.; Tada, Y.N.; Spivey, W.; Genschik, P.; Dong, X. Proteasome-mediated turnover of the transcription coactivator NPR1 plays dual roles in regulating plant immunity. Cell 2009, 137, 860-872. [CrossRef] [PubMed]

129. Más, P.; Alabadí, D.; Yanovsky, M.J.; Oyama, T.; Kay, S.A. Dual role of TOC1 in the control of circadian and photomorphogenic responses in Arabidopsis. Plant Cell 2003, 15, 223-236. [CrossRef] [PubMed]

130. Brody, S.; Harris, S. Circadian rhythms in neurospora: Spatial differences in pyridine nucleotide levels. Science 1973, 180, 498-500. [CrossRef] [PubMed]

131. Dangl, J.L.; Jones, J.D. Plant pathogens and integrated defence responses to infection. Nature 2001, 411, 826-833. [CrossRef] [PubMed]

132. Frederickson Matika, D.E.; Loake, G.J. Redox regulation in plant immune function. Antioxid. Redox Signal. 2014, 21, 1373-1388. [CrossRef] [PubMed]

133. Delledonne, M.; Zeier, J.; Marocco, A.; Lamb, C. Signal interactions between nitric oxide and reactive oxygen intermediates in the plant hypersensitive disease resistance response. Proc. Natl. Acad. Sci. USA 2001, 98, 13454-13459. [CrossRef] [PubMed]

134. Levine, A.; Tenhaken, R.; Dixon, R.; Lamb, C. $\mathrm{H}_{2} \mathrm{O}_{2}$ from the oxidative burst orchestrates the plant hypersensitive disease resistance response. Cell 1994, 79, 583-593. [CrossRef]

135. Yun, B.W.; Feechan, A.; Yin, M.; Saidi, N.B.; Le, B.T.; Yu, M.; Moore, J.W.; Kang, J.G.; Kwon, E.; Spoel, S.H.; et al. S-nitrosylation of NADPH oxidase regulates cell death in plant immunity. Nature 2011, 478, 264-268. [CrossRef] [PubMed]

136. Yuan, H.M.; Liu, W.C.; Lu, Y.T. Catalase2 coordinates SA-mediated repression of both auxin accumulation and JA biosynthesis in plant defenses. Cell Host Microbe 2017, 21, 143-155. [CrossRef] [PubMed]

137. Covington, M.F.; Maloof, J.N.; Straume, M.; Kay, S.A.; Harmer, S.L. Global transcriptome analysis reveals circadian regulation of key pathways in plant growth and development. Genome Biol. 2008, 9, 2-18. [CrossRef] [PubMed]

138. Zhong, H.H.; McClung, C.R. The circadian clock gates expression of two Arabidopsis catalase genes to distinct and opposite circadian phases. Mol. Gengenet. 1996, 251, 196-203.

139. Bhattacharya, A.; Khanale, V.; Char, B. Plant circadian rhythm in stress signaling. Indian J. Plant Physiol. 2017, 22, 147-155. [CrossRef] 
140. Jahan, M.S.; Ogawa, K.; Nakamura, Y.; Shimoishi, Y.; Mori, I.C.; Murata, Y. Deficient glutathione in guard cells facilitates abscisic acid-induced stomatal closure but does not affect light-induced stomatal opening. J. Agric. Chem. Soc. Jpn. 2008, 72, 2795-2798. [CrossRef] [PubMed]

141. Lu, H.; Mcclung, C.R.; Zhang, C. Tick tock: Circadian regulation of plant innate immunity. Annu. Rev. Phytopathol. 2017, 55, 287-311. [CrossRef] [PubMed]

142. Spoel, S.H.; Van, O.G. Circadian redox signaling in plant immunity and abiotic stress. Antioxid. Redox Signal. 2014, 20, 3024-3039. [CrossRef] [PubMed]

143. Kadota, Y.; Sklenar, J.; Derbyshire, P.; Stransfeld, L.; Asai, S.; Ntoukakis, V.; Jones, J.D.; Shirasu, K.; Menke, F.; Jones, A.; et al. Direct regulation of the NADPH oxidase RBOHD by the PRR-associated kinase BIK1 during plant immunity. Mol. Cell 2014, 54, 43-55. [CrossRef] [PubMed]

144. Li, L.; Li, M.; Yu, L.; Zhou, Z.; Liang, X.; Liu, Z.; Cai, G.; Gao, L.; Zhang, X.; Wang, Y.; et al. The FLS2-associated kinase BIK1 directly phosphorylates the NADPH oxidase rbohd to control plant immunity. Cell Host Microbe 2014, 15, 329-338. [CrossRef] [PubMed]

145. Chaouch, S.; Queval, G.; Noctor, G. ATRbohF is a crucial modulator of defence-associated metabolism and a key actor in the interplay between intracellular oxidative stress and pathogenesis responses in Arabidopsis. Plant J. 2012, 69, 613-627. [CrossRef] [PubMed]

146. Mammarella, N.D.; Cheng, Z.; Zheng, Q.F.; Daudi, A.; Bolwell, G.P.; Dong, X.; Ausubel, F.M. Apoplastic peroxidases are required for salicylic acid-mediated defense against Pseudomonas syringae. Phytochemistry 2015, 112, 110-121. [CrossRef] [PubMed]

147. Daudi, A.; Cheng, Z.; O’Brien, J.A.; Mammarella, N.; Khan, S.; Ausubel, F.M.; Bolwell, G.P. The apoplastic oxidative burst peroxidase in Arabidopsis is a major component of pattern-triggered immunity. Plant Cell 2012, 24, 275-287. [CrossRef] [PubMed]

148. O’Brien, J.A.; Daudi, A.; Finch, P.; Butt, V.S.; Whitelegge, J.P.; Souda, P.; Ausubel, F.M.; Bolwell, G.P. A peroxidase-dependent apoplastic oxidative burst in cultured Arabidopsis cells functions in MAMP-elicited defense. Plant Physiol. 2012, 158, 2013-2027. [CrossRef] [PubMed]

149. Bindschedler, L.V.; Dewdney, J.; Blee, K.A.; Stone, J.M.; Asai, T.; Plotnikov, J.; Denoux, C.; Hayes, T.; Gerrish, C.; Davies, D.R.; et al. Peroxidase-dependent apoplastic oxidative burst in Arabidopsis required for pathogen resistance. Plant J. 2006, 47, 851-863. [CrossRef] [PubMed]

150. Melotto, M.; Underwood, W.; Koczan, J.; Nomura, K.; He, S.Y. Plant stomata function in innate immunity against bacterial invasion. Cell 2006, 126, 969-980. [CrossRef] [PubMed]

151. Zeidler, D.; Zähringer, U.; Gerber, I.; Dubery, I.; Hartung, T.; Bors, W.; Hutzler, P.; Durner, J. Innate immunity in Arabidopsis thaliana: Lipopolysaccharides activate nitric oxide synthase (NOS) and induce defense genes. Proc. Natl. Acad. Sci. USA 2004, 101, 15811-15816. [CrossRef] [PubMed]

152. Durner, J.; Wendehenne, D.; Klessig, D.F. Defense gene induction in tobacco by nitric oxide, cyclic GMP, and cyclic ADP-Ribose. Proc. Natl. Acad. Sci. USA 1998, 95, 10328-10333. [CrossRef] [PubMed]

153. Sun, A.; Nie, S.; Xing, D. Nitric oxide-mediated maintenance of redox homeostasis contributes to NPR1-dependent plant innate immunity triggered by lipopolysaccharides. Plant Physiol. 2012, 160, 1081-1096. [CrossRef] [PubMed]

(C) 2019 by the authors. Licensee MDPI, Basel, Switzerland. This article is an open access article distributed under the terms and conditions of the Creative Commons Attribution (CC BY) license (http://creativecommons.org/licenses/by/4.0/). 